\title{
Discourse Markers and Plagiarism in the Literature Review Section of a Research Thesis: A Study in Kenya
}

\author{
Emily Ayieta Ondondo*, Francis Owino Rew \\ Science and Technology (JOOUST), Bondo, Kenya \\ Email address: \\ eondondo@gmail.com (E. A. Ondondo), iceprew@gmail.com (F. O. Rew) \\ ${ }^{*}$ Corresponding author
}

Department of Linguistics, Languages and Literature, School of Humanities and Social Sciences, Jaramogi Oginga Odinga University of

\section{To cite this article:}

Emily Ayieta Ondondo, Francis Owino Rew. Discourse Markers and Plagiarism in the Literature Review Section of a Research Thesis: A Study in Kenya. Communication and Linguistics Studies. Vol. 6, No. 2, 2020, pp. 27-33. doi: 10.11648/j.cls.20200602.13

Received: May 14, 2020; Accepted: May 28, 2020; Published: June 4, 2020

\begin{abstract}
Academic writing is pertinent to postgraduate students because it is mandatory for them to write a research thesis as part of their degree programme. However, sometimes the theses that postgraduate students write do not communicate well or depict their professionalism. One of the problems these students face, as they write, is appropriate use of discourse markers. Discourse markers, when used appropriately, enhance coherence and signal the presence of particular relationships among text elements. They are also crucial tools for achieving communicative act in the text because they guide and influence the text-receivers' interpretation of the text. To evaluate how postgraduate students in Kenya use discourse markers in their writing, as speakers of English as a second language, this paper analyzed the discourse markers in the literature review section of all the $\mathrm{PhD}$ theses deposited at JOOUST library. If postgraduate students use Discourse markers effectively, especially in the literature review section of their theses, this could help guard against plagiarism because their voices as writers will be forcefully brought out. Basing on Fraser's taxonomy the study identified different hierarchies of discourse markers though elaborative and inferential markers were the most frequent types. The study also suggested how some of the discourse markers identified could be used to bring out the writer's voice so as to guard against plagiarism.
\end{abstract}

Keywords: Discourse Analysis, Discourse Markers, Form, Function, Thesis Writing, Plagiarism

\section{Introduction}

In academia, writing is an essential skill that is required in almost every activity that learners engage in during their study periods. Doctoral thesis writing not only requires linguistic competence (the knowledge of morphology and syntax) but also requires particular writing skills pertinent to thesis writing [1-4]. This means that developing writing skills, as a $\mathrm{PhD}$ student, is a complex and difficult task. Thesis writing is different from composition writing because it is based on investigated facts. It is a form of professional writing which requires the learners to acquire its critical skills and conventions.

As a form of discourse, a doctoral thesis needs to function together to convey a given idea or information. The linguistic devices that are used to hang the pieces of language or expression, in a doctoral thesis, together are called discourse markers [1, 4-10]. Discourse markers are used to show or signal the relationship between ideas or information in the text $[8,11-12]$. They are words or phrases used by writers to link ideas or information in a discourse [13-15, 49]. Without sufficient discourse markers in a piece of writing, a text would not seem logically constructed and the connections between the different sentences and paragraphs would not be obvious $[1,6,9]$. Besides, discourse markers also guide the reader predict the direction of the flow of discourse [16]. Therefore, the primary function of discourse markers is to explicitly signal the connections between passages of text and to state the writer's perception of the relationship between two units of discourse [1, 17]. In this way, discourse markers do not contribute to the truth-conditional content. Instead, they help reduce the listener's processing effort by limiting the range of interpretive hypotheses $\mathrm{s} /$ he has to consider. Thus, they contribute to an increase of the efficiency of communication $[5,12,14,17-20,49]$.

Writing has been proven to be the most difficult language 
skill even for native speakers [21]. It, therefore, seems reasonable to suppose that inappropriate use of discourse markers in a second language could, to a certain extent, hinder successful communication, leading to a misunderstanding between message sender and receiver [22]. Effective use of discourse markers has been seen as a central component in academic writing [23-25] and lack of it has been regarded as a sign for novice and apprentice L2 writers [24-26]. Given that doctoral thesis writers at JOOUST use English as a second language, the present study sought to investigate how they use discourse markers to write in a way that makes the message clear, succinct, and easily interpretable for the readers. More importantly, the study investigated how doctoral thesis writers use discourse markers to guard against plagiarism, something which has not been considered before in the existing literature on discourse markers in academic writing.

\section{Objectives}

The study was guided by three objectives:

1. To identify the types of discourse markers used in research thesis writing.

2. To describe the function of the discourse markers used in research thesis writing.

3. To suggest how the discourse markers used in research thesis writing could be used to bring out the writer's voice.

\section{Research Questions}

This study was based on three questions:

1. What discourse markers are used in research thesis writing?

2. What functions do the discourse markers used in research thesis writing play?

3. How could the discourse markers used in research thesis writing bring out the writer's voice?

\section{Literature Review}

Discourse markers provide information at the discourse level and not at the sentence level [27]. Therefore, the focus of the functions of discourse markers in this study is based on the text as a whole, which views connected discourse as central to understanding language and grammar [28-37]. This is contrary to the traditional view that limits the understanding of language to the sentence level but supports the modern view that argues that textual units have a lot to offer in language use and understanding [36].

In functional linguistics, where this study falls, the understanding of grammar goes beyond the level of the sentence to the level of the text as a whole [32]. This is because certain factors are needed for the understanding of elements in sentences, which lie outside the sentences themselves but are found elsewhere in the discourse [31]. The essence of this is that dissociating grammatical phenomena from the structure of texts underscores their use. The importance of discourse in studying language is that it brings out the valuable information that the interrelations of individual words express when they are joined with one another.

Written discourse, just like spoken discourse constitutes a text that should have texture as its defining principle $[8,29]$. To communicate, every text needs to be cohesive and coherent, and every coherent text has some sort of structure (texture), which ties the segments of the text together, so that the text as a whole is perceived as one unit $[8,29,38]$. Therefore, the interpretation of what a writer is talking about is arguably based on how the writer structures what $\mathrm{s} /$ he is saying. In this way, a text is not just strings of sequences of language items that are linearly produced and received. Instead, it follows a hierarchy of content, so that as each new part of the message is transmitted, it is not added on the end of a string, but rather takes its place in a complex interrelated structure [39]. This points to the fact that every writer is faced with the problem of how to organize and present his/her non-linear message in a comprehensible linear form.

The structure of written discourse is governed by cohesion and coherence of the text. Cohesion explicitly ties together related parts of the text. It combines with both intra-sentence structure and inter-sentence cohesion to provide the total text-forming resources [8, 40-41]. Coherence, on the other hand, provides an abstract semantic description of the global content of the discourse [42]. This is because, the meaning of texts cannot be adequately described at the local level of sentences and sentence connections alone but it should also be specified at more global levels [42]. It is, therefore, assumed that what is communicated in a text is more than the semantic content of the individual text segments. Part of the meaning of discourse is the relationship between sentences and larger discourse units [43-44].

A text is a communicative event. This imply that its structure is not a static entity but a dynamic one that is interactively produced and processed [8, 45]. Given that texts are communicative events that involve interaction between the writer and the reader, they can be said to be intentional and inferential [34]. In this sense texts can be seen as a result of a dynamic process in which writers express meaning and achieve intentions and readers recognize these intentions [20]. As a result, writers are engaged in more than merely conveying propositional content. When they write, they present the propositional content as making sense, and at the same time present the same content as fulfilling their purpose. Therefore, each segment of text encodes pragmatic information that signals the writer's communicative intentions and contributes to achieving the overall discourse purpose [46-47]. The reader, on the other hand, has no access to the writer's intended meaning in producing a given text. The reader's interpretation of the coherence of a text only depends on a process of inferences of what the writer means [29].

Given that the main criterion for generating effective text is to achieve the communicative objective of the writer, the writer's intentions play a major role in explaining discourse structure and defining discourse coherence [47]. The writer is 
significantly involved in how the reader will perceive the relations between the segments of the text according to his/her intentions. In order to successfully communicate his/her message, the writer seeks to make these intentions clearly recognizable and inferable from the text. Discourse markers are useful linguistic tools for clarifying the writer's communicative intentions. They signal how the writer intends a message to relate to the foregoing or following discourse or to a particular aspect of the communicative situation [48]. Underlying the description of discourse markers in this study, therefore, is the assumption that they perform not only connective but also communicative functions. This implies that the writer uses discourse markers to signal to the reader what $s / h e$ is doing in the text and to influence the reader's understanding of what $\mathrm{s} /$ he saying. The reader, in turn, uses these linguistic expressions to postulate the writer's goals and intentions, which guide his/her interpretation process. The present study, therefore, investigated how Doctoral students at JOOUST use discourse markers to signal their intentions and influence their readers' recognition and understanding of these intentions in their research theses.

\section{Theoretical Framework}

The main framework adopted in this study is Fraser's taxonomy of discourse markers [49]. Though Fraser's taxonomy was the main taxonomy adopted in this study, some aspects of other taxonomies [7] were also incorporated in order to meet the aims of the current study. After integrating the aspects from Cowan into Fraser's taxonomy, the resultant model as used in this study is as summarised in table 1 below. This study, therefore, presents a new model for academic and non-academic writing.

Table 1. A model of discourse markers in texts.

\begin{tabular}{|c|c|c|}
\hline Category & Function & Examples \\
\hline Contrastive markers & Show contrast between sentences & but, however \\
\hline Elaborative Markers & Demonstrate similarity between sentences & and, moreover, in addition \\
\hline Inferential Markers & Refer to conclusion from preceding sentences & so, therefore \\
\hline Conclusive Markers & Show conclusion to what has been mentioned before. & in sum, in conclusion, to sum up \\
\hline Reason Markers & Provide reasons for the content of preceding sentences & because, since \\
\hline Exemplifier Markers & Provide examples for the content of preceding sentences & for example, for instance \\
\hline Topic relating markers & Relate the topic of the second sentence to the first sentence. & back to my original point, by the way, with regards to \\
\hline Attitudinal markers & $\begin{array}{l}\text { Expressing the writer's attitude regarding the truth of preceding content } \\
\text { and introducing content in support of cognitive stance }\end{array}$ & in fact, indeed \\
\hline Transition markers & Function as cues to direct the reader's attention & I think, in my opinion \\
\hline
\end{tabular}

\section{Methodology}

The study analysed the literature review section of a corpus of $20 \mathrm{PhD}$ theses distributed across all disciplines as follows: Linguistics, History, Geography, Education Administration and Management, Guidance and Counselling, Educational Psychology, Pure Mathematics, Applied Mathematics, Planning, Finance, Health, Strategic Management, Informatics, Information Technology, Food Security, Botany, Logistics and Supply Chain Management, Agribusiness Management, Special Needs Education, Early Childhood Development and Education. These were selected randomly from the 74, hard copy, $\mathrm{PhD}$ theses deposited at JOOUST library, at the main campus in Bondo from 2014 to 2018. Those not deposited in the JOOUST library at the main campus were not considered in this study. The University had its first graduation as a fully-fledged university with its own charter in May 2014. The literature review section of the theses was chosen because it is in this section that writers of $\mathrm{PhD}$ research theses need to synthesis views of other scholars in the field with their own; something that requires careful and accurate use of discourse markers. As they do this, they need to situate their research and its significance in the existing literature and at the same time try as much as possible to avoid plagiarizing other scholars' works.

The discourse markers used in the literature review section of the theses were identified manually, from each thesis, according to the categories highlighted in the model adopted in this study. The functions of the discourse markers identified were then described. Finally, how the identified discourse markers could be used to bring out the writer's voice was suggested. In order to do this as accurately and precisely as possible a rigorous contextual analysis, of these markers, was carried out from a linguistic standpoint and as per the taxonomy adopted in this research.

\section{Findings}

There was a total of one thousand two hundred and thirty-two (1232) discourse markers identified in the corpus. The survey of the texts revealed that there are instances of over use of particular discourse markers such as also, because, however, despite, therefore, and, thus, in addition, for example among others. This agrees with the findings of other works [25, 50-57]. The details of the findings of the study are summarised in table 2 below. 
Table 2. Distribution of discourse markers in the corpus.

\begin{tabular}{|c|c|c|c|c|}
\hline No & Category & Function & Resources & Total \\
\hline 1 & $\begin{array}{l}\text { Contrastive \& } \\
\text { comparison } \\
\text { markers }\end{array}$ & Show contrast between sentences & $\begin{array}{l}\text { But, however, on one hand, on the other hand, contrastingly, } \\
\text { contrastively, contrary, disagree (s), contrasts on the other side, } \\
\text { although, in spite, despite, though, as opposed to, as compared to, as } \\
\text { well as, like, equally, nevertheless, while }\end{array}$ & 21 \\
\hline 2 & $\begin{array}{l}\text { Elaborative } \\
\text { Markers }\end{array}$ & $\begin{array}{l}\text { Demonstrate similarity between sentences } \\
\text { by adding something or information }\end{array}$ & $\begin{array}{l}\text { And, moreover, in addition, furthermore, also, additionally, besides, } \\
\text { more so, another, not only that, not only this, as far as, as long as, to } \\
\text { add to that, the other, adds that, apart from, again }\end{array}$ & 18 \\
\hline 3 & $\begin{array}{l}\text { Inferential } \\
\text { Markers }\end{array}$ & $\begin{array}{l}\text { Refer to conclusion from preceding } \\
\text { sentences }\end{array}$ & So, therefore, thus, as a result, accordingly, arguably, in this regard & 7 \\
\hline 4 & $\begin{array}{l}\text { Conclusive } \\
\text { Markers }\end{array}$ & $\begin{array}{l}\text { Show conclusion to what has been } \\
\text { mentioned before }\end{array}$ & In sum, in conclusion, to sum up, have concluded, concludes that, & 5 \\
\hline 5 & Reason Markers & $\begin{array}{l}\text { Provide reasons for the content of } \\
\text { preceding sentences }\end{array}$ & Because, since, thus, for this reason, due to, due to the fact that & 6 \\
\hline 6 & $\begin{array}{l}\text { Exemplifier } \\
\text { Markers }\end{array}$ & $\begin{array}{l}\text { Provide examples for the content of } \\
\text { preceding sentences }\end{array}$ & $\begin{array}{l}\text { For example, for instance, such as, illustrates, illustrated, examples } \\
\text { like, an example, }\end{array}$ & 7 \\
\hline 7 & Ordering markers & $\begin{array}{l}\text { Ordering the main points that writers want } \\
\text { to make and indicating a sequence of step }\end{array}$ & First, the first, firstly, second, the second, the third, lastly, finally & 8 \\
\hline 8 & Relating markers & $\begin{array}{l}\text { Relate the topic of the second sentence to } \\
\text { the first sentence }\end{array}$ & $\begin{array}{l}\text { Back to my original point, by the way, with regard to, in } \\
\text { concurrence }\end{array}$ & 4 \\
\hline 9 & $\begin{array}{l}\text { Attitudinal } \\
\text { markers }\end{array}$ & $\begin{array}{l}\text { Express the writer's attitude regarding the } \\
\text { truth of preceding content and introducing } \\
\text { content in support of cognitive stance }\end{array}$ & In fact, indeed, in particular & 3 \\
\hline 10 & Transition markers & $\begin{array}{l}\text { Function as cues to direct the reader's } \\
\text { attention }\end{array}$ & $\begin{array}{l}\text { I think, in my opinion, in this case, in this sense, in the light of this, } \\
\text { in this view, by this, to this end, to this effect, in support, the same } \\
\text { case, as stated earlier, this means, mentioned above, alluded to } \\
\text { above }\end{array}$ & 15 \\
\hline
\end{tabular}

As the data in table 2 above shows, ten classes of discourse markers were identified in the corpus according to function. They include contrastive and comparison markers, elaborative markers, inferential markers, conclusive markers, reason markers, exemplifier markers, ordering markers, relating markers, attitudinal markers and transition markers.

\section{Discussion}

The findings of this study show that of the ten categories of the discourse markers identified in the corpus, contrastive and comparison markers constituted the majority. There were 21 types of these markers as shown in table 2 above. Contrastive markers such as but, however, on the other hand, contrary, although, despite, were mainly used to show contrast between sentences, while comparison markers, such as, like, equally, while, were used to show comparison between sentences. There were more contrastive markers compared to comparison markers. The most common contrast markers in the corpus were but, however, although, despite and on the other hand.

Elaborative markers, such as and, moreover, in addition, furthermore, also, additionally, came in second at 18. Elaborative markers were used to demonstrate similarity between sentences by adding something or information to what had already been given in the foregoing sentence (s). In third position were transition markers at 15 . These discourse markers, such as in my opinion, in this case, by this, to this effect, in support, as stated earlier, this means, mentioned above, were used as cues to direct the reader's attention in the texts. In fourth position were ordering markers at 8 . Such ordering markers as first, the first, firstly, second, the second, the third, lastly, finally were identified in the corpus. They were used to order the main points that the writers were making and at the same time to indicate sequences of steps. Inferential markers such as so, therefore, thus, as a result, accordingly, arguably, in this regard and exemplifier markers such as for example, for instance, such as, illustrates, illustrated, examples like, an example came in fifth position at 7 each. The writers used inferential markers to refer to conclusion from preceding sentences and exemplifier markers to provide examples for the content of preceding sentences.

In sixth position were reason markers at 6 . These markers included examples such as because, since, thus, for this reason, due to, due to the fact that. The writers used these markers to provide reasons for the content of preceding sentences. After these in seventh position were conclusive markers at 5 . They included such markers as in sum, in conclusion, to sum up, have concluded, concludes that, and were used by the writers to show conclusion to what has been mentioned before.

Relating markers and attitudinal markers came in eighth and ninth position at 4 and 3 respectively. Some of the relating markers identified in the corpus included markers such as back to my original point, by the way, with regard to, in concurrence. They were mainly used by the writers to relate the topic of the second sentence to the first sentence. Attitudinal markers, on the other hand, included markers such as in fact, indeed, in particular. The writers used them to express their attitude regarding the truth of preceding content and to introduce content in support of their cognitive stances.

The preceding discussion shows that research thesis writers at JOOUST use discourse markers in their writing. However, it was observed that they do not use discourse markers appropriately to bring out their voice in synthesising the 
literature incorporated in the literature review section. In this way, their voice, which could help in guarding against plagiarism and making the writing coherent is not felt or heard. In many of the research thesis sampled in this study, the writers present the information in the literature review section by mentioning the authors and what they said. The patterns observed in the corpus of the study are outlined below.

According to Amanuel 2009...

Okumbe (1999) singled out/observed that/classifies/suggested/postulates/states/ analysing/ carried out a study/studies...

Other scholars such as Okumbe (1999) and Horsolma (2002) have pointed out that...

A study by Milimu (2008) points out that/states...

Indoshi's (2000) study revealed...

These patterns were presented in two main ways in the sampled research theses. First, the writers presented the views of each author in separate paragraphs one after the other. Second, the writers stacked the views of each author in the same paragraph. These presentations make the writing unnatural and not synthesised. The writing is then rendered incohesive and incoherent. At the same time the writing is eluded of the writer's voice and seen as pieces of information from different authors copied and pasted in the literature review section. Discourse markers, if used appropriately, could help research thesis writers put in force their voice in the writing of literature review.

Instead of research thesis writers presenting the views of each author in separate paragraphs using any or a mixture of the formats discussed above, they could synthesis the views from the different authors and present them in a cohesive and coherent way by the use of discourse markers. For instance, a writer could begin a paragraph and develop it as suggested below by the use of discourse markers. The discourse markers in question are shown in bold face.

According to Amanuel (2009), discourse markers could help a great deal in making research thesis writing cohesive and coherent. While, Okumbe (1999) disagrees with the idea that discourse markers help produce cohesive and coherent writing, he acknowledges that discourse markers are important in research thesis writing. In the same way, a study by Milimu (2008) points out that discourse markers are important in research thesis writing because they help make the writing synthesized, easy to read and comprehensible to the reader. Therefore, the importance of discourse markers in research thesis writing cannot be overlooked as reiterated by other scholars such as Indoshi (2000) and Horsolma (2002).

Instead of the writers stacking the views of each author in the same paragraph one after the other, they could use discourse markers to link the views to make the paragraph cohesive and coherent. Consider the suggestion below. The discourse markers used are shown in bold face.

While other scholars such as Okumbe (1999) and Horsolma (2002) have painted discourse markers negatively, others have viewed it positively. For instance, Wango (2008) views discourse markers as important devices in producing effective research thesis writing. Indoshi (2000), on the other hand, sees discourse markers as pertinent to research thesis writing for the reason that they help improve readability of their writing.

There is yet another pattern of presentation that was identified in the corpus of the sampled theses. In this pattern, writers were seen to present ideas from different scholars one after the other in a paragraph and indicating the authors, names after each idea as shown below.

These policies ensure... (Ogunyem, 2006). The policies should encourage... (Schwane, 2005). Security of other policies should... (Gibbs et al (2002). The policies need to ... (Petrazzin \& Kibali, 1999) and ... (Schane, 2000).

A paragraph in this format could be reconstructed with the use of discourse markers as suggested below.

These policies ensure... (Ogunyem, 2006). However, the policies should encourage... (Schwane, 2005). In addition, security of other policies should... (Gibbs et al (2002). In this regard, the policies need to... (Petrazzin \& Kibali, 1999) and... (Schane, 2000).

\section{Conclusion}

Considering all said above, it can be concluded that writing effectively and fluently in a coherent way necessitates the acquisition of discourse markers and their optimal and appropriate use. The problem with discourse makers for research thesis writers in JOOUST as users of English as a second language just like other L2 writers occurs in three ways. First, they overuse a limited number of well-known markers. Second, they do not possess the existing wide repertoire to use discourse markers in a native-like manner. Third, they do not use discourse markers to bring out their voice in the writing. Therefore, research thesis writers at JOOUST use discourse markers in a very simplistic and largely inappropriate way in their written works. Given that the presence and effective use of discourse markers mark the writer's familiarity with the register of a certain academic community, research thesis writers at JOOUST should learn and use discourse markers appropriately for prospective success in their field of study. Therefore, teaching and learning appropriate and effective use of discourse markers should be an essential component in academic writing courses offered to research thesis writers.

\section{References}

[1] Biber, D., Johansson, S., Leech, G., Conrad, S., \& Finegan, E. (1999). The Grammar of Spoken and Written English. Harlow, UK: Pearson Education.

[2] Hu, M., \& Nation, I. S. P. (2000). Unknown Vocabulary Density and Reading Comprehension. Reading in a Foreign Language, 13 (1), 403-430.

[3] Nattinger, J. R., \& DeCarrico, J. S. (1992). Lexical Phrases and Language Teaching. Oxford: Oxford University Press.

[4] Wray, A. (2002). Formulaic Language and the Lexicon. Cambridge: Cambridge University Press. 
[5] Blakemore, D. (1987). Semantic Constraints on Relevance. Oxford: Blackwell.

[6] Celce-Murcia, M., \& Larsen-Freeman, D. (1999). The Grammar Book: An ESL/ EFL Teacher's Course (2nd ed.). Boston: Heinle \& Heinle.

[7] Cowan, R. (2008). The teacher's grammar of English. Cambridge: Cambridge University Press.

[8] Halliday, M. A. K., \& Hasan, R. (1976). Cohesion in English. London: Longman.

[9] Huddleston, R., \& Pullum, G. K. (2002). The Cambridge Grammar of the English Language. Cambridge: Cambridge University Press.

[10] Quirk, R., Greenbaum, S., Leech, G., \& Svartvik, J. (1985). A Comprehensive Grammar of the English Language. London: Longman.

[11] Biber, D., \& Barbieri, F. (2007). Lexical bundles in university spoken and written registers. English for Specific Purposes, 26, 263-286.

[12] Hernandez, T. (2008). Effect of Explicit Instruction and Input Flood on Students' Use of Spanish Discourse Markers on a Simulated Oral Proficiency Interview. Hispania, 91 (3), 665-675.

[13] Fraser, B. (1998). Contrastive discourse markers in English. In A. Jucker \& Y. Ziv (Eds.), Discourse Markers: Description and Theory (pp. 301-326). Philadelphia: Benjamins.

[14] Gerard, S. (2000). Discourse Markers. Centre for Applied Linguistics. Learning English online at Warwick.

[15] Wei, M. (2011). A Comparative Study of the Oral Proficiency of Chinese Learners of English across Task Functions: A Discourse Marker Perspective. Foreign Language Annals, 44 (4), 674-691.

[16] Barnabas J., \& Adamu, M. (2012). Discourse Markers in Nigerian Television News Broadcast. British Journal of Humanities and Social Sciences, 8 (1), 44-56.

[17] Redeker, G. (1991). Review Article: Linguistic Markers of Discourse Structure. Linguistics, 29 (6), 1139-1172.

[18] Dulger, O. (2007). Discourse markers in writing. Selçuk Üniversitesi Sosyal Bilimler Enstitüsü Dergisi, 18, 257-270.

[19] Lenk, U. (1998). Marking Discourse Coherence: Functions of Discourse Markers in Spoken English. Tubingen, Germany: Gunter Narr Verlag.

[20] Schiffrin, D. (2001). Discourse Markers: Language, Meaning and Context. In D. Schiffrin, D. Tannen, \& H. E. Hamilton (Eds.), The Handbook of Discourse Analysis (pp. 54-75). Oxford: Blackwell.

[21] Norrish, J. (1983). Language Learners and their Errors. London: The Macmillan Press Ltd.

[22] Warsi, J. (2000). The Acquisition of English Contrastive Discourse Markers by Advanced Russian ESL Students. Ph. D. Thesis. Boston University.

[23] Coxhead, A., \& Byrd, P. (2007). Preparing writing teachers to teach the vocabulary and grammar of academic prose. Journal of Second Language Writing, 16, 129-147.
[24] Hyland, K. (2008). As Can Be Seen: Lexical Bundles and Disciplinary Variation. English for Specific Purposes, 27, 4 21.

[25] Li, J., \& Schmitt, N. (2009). The Acquisition of Lexical Phrases in Academic Writing: A Longitudinal Case Study. Journal of Second Language Writing, 18, 85-102.

[26] Haswell, R. (1991). Gaining Ground in College Writing: Tales of Development and Interpretation. Dallas, TX: Southern Methodist University Press.

[27] Matras, Y. (1997). The Function and Typology of Coordinating Conjunctions: Evidence from Discourse and Language-Contact Situations. In John H. Connolly, Roel M. Vismans, Christopher S. Butler, and Richard A. Gatward (Eds.). Discourse and Pragmatics in Functional Grammar 177-191. Berlin/New York: Mouton de Gruyter.

[28] de Beaugrande, R. (1994). Discourse Analysis. In M. Groden \& M. Kreiswirth (Eds.). The Johns Hopkins Guide to Literary Theory and Criticism, 207- 210. Baltimore: The Johns Hopkins University Press.

[29] Brown, G \& Yule, G. (1986). Discourse Analysis. Cambridge/New York: Cambridge University Press.

[30] Cumming, S \& Tsuyoshi, O. (1997). Discourse and Grammar. In Teun A. van Dijk (Eds.). Discourse as Structure and Process, 112-137. London: Sage.

[31] Grimes, J. E. (1975). The Thread of Discourse. New York/Amsterdam: Mouton Publishers.

[32] Halliday, M. A. K. (2004). An Introduction to Functional Grammar. London: Hodder Arnold.

[33] Hatim, B. (1997). Communication across Cultures: Translation Theory and Contrastive Text Linguistics. Exeter: University of Exeter Press.

[34] Hoey, M. (2001). Textual Interaction: An Introduction to Written Discourse Analysis. London/New York: Routledge.

[35] Hoey, M. (2002). Textual Colligation: A Special Kind of Lexical Priming. In Karin Aijmer, and Bengt Altenberg (Eds.). Advances in Corpus Linguistics: Papers from the 23rd International Conference on English Language Research on Computerized Corpora (ICAME 23). Amsterdam/New York: Göteborg.

[36] Longacre, R. E. (1996). The Grammar of Discourse, 2nd edition. New York/London: Plenum Press.

[37] Morgan, J. L \& Sellner, M. B. (1980). Discourse and linguistic theory. In Rand, J. Spiro, Bertram C. Bruce \& William F. Brewer (Eds). Theoretical Issues in Reading Comprehension: Perspective from Cognitive Psychology, Linguistics, Artificial Intelligence, and Education, 163-200. New Jersey: Lawrence Erlbaum Associates, Inc.

[38] Reinhart, T. (1980). Conditions for Text Coherence. Poetics Today 1 (4), 161-80.

[39] Callow, K. (1998). Man and Message: A Guide to Meaning-Based Text Analysis. New York/Oxford: Summer Institute of Linguistics, Inc. and University Press of America.

[40] Graustein, G \& Thiele, W. (1987). Properties of English Texts. Leipzig: Veb Verlag Enzyklopädie.

[41] Hinds, J. (1977). Paragraph Structure and Pronominalization. Papers in Linguistics, 10, 77-99. 
[42] Van Dijk, T. A. (1983). Strategies of Discourse Comprehension. London/New York: Academic Press.

[43] Cawsey, A. (1990). Generating Explanatory Discourse. In Robert Dale, Chris Mellish \& Michael Zoch (Eds.). Current Research in Natural Language Generation, 75-101. London/New York: Academic Press.

[44] Hovy, E. H. (1990). Unresolved Issues in Paragraph Planning. In Robert Dale, Chris Mellish, and Michael Zock (Eds.). Current Research in Natural Language Generation, 17-45. San Diego: Academic Press Inc.

[45] De Beaugrande, R \& Dressler, W. U. (1981). Introduction to Text Linguistics. London/New York: Longman.

[46] Fraser, B. (1990). An Approach to Discourse Markers. Journal of Pragmatics, 14, 383- 395.

[47] Grosz, B. J. \& Sidner, C. L. (1986). Attention, Intentions, and the Structure of Discourse. Computational Linguistic, 12 (3), 175-204.

[48] Kroon, C. (1997). Discourse Markers, Discourse Structure and Functional Grammar. In John H. Connolly, Roel M. Vismans, Christopher S. Butler, and Richard A. Gatward (Eds.). Discourse and Pragmatics in Functional Grammar, 17-32. Berlin/New York: Mouton de Gruyter.

[49] Fraser, B. (1999). What are discourse markers? Journal of Pragmatics, 31, 931-952.

[50] Crowhurst, M. (1987). Cohesion in argument and narration at three grade levels. Research in the leaching of English, 21, 185-201.
[51] Granger, S. (1998). Prefabricated patterns in advanced EFL writing: Collocations and formulae. In A. P. Cowie (Ed.), Phraseology: Theory, analysis, and applications (pp. 145160). Oxford: Oxford University Press.

[52] Howarth, P. (1998). The Phraseology of Learners' Academic Writing. In A. P. Cowie (Ed.), Phraseology: Theory, analysis, and applications (pp. 161-186). Oxford: Oxford University Press.

[53] Schleppegrell, M. J. (1996). Conjunctions in Spoken English and ESL Writing. Applied Linguistics, 17, 271-285.

[54] Sharndama, E. C., \& Yakubu, S. (2013). An Analysis of Discourse Markers in Academic Report Writing: Pedagogical Implications. International Journal of Academic Research and Reflection, 1 (3), 15-24.

[55] Adewibowo, D., Imranuddin, \& Azwandi. (2018). A Study of Discourse Markers used in the Thesis Background Written by the Students of English Department of Bengkulu University. Journal of English Education and Teaching (JEET), 2 (3), 89-97.

[56] Sandholtet, M. (2018). Discourse Markers in Written Learner English: A Corpus-based Study of the Discourse Markers "so, like, actually, anyway, well, you know, and I mean" in Written Norwegian Learner Language. MA Thesis University of Oslo.

[57] Hasniar. (2017). Discourse Markers used in Brad Bird's Movie "Tomorrowland". MA Thesis Alauddin State Islamic University Maskassar. 